DIW BERLIN

Discussion

Papers

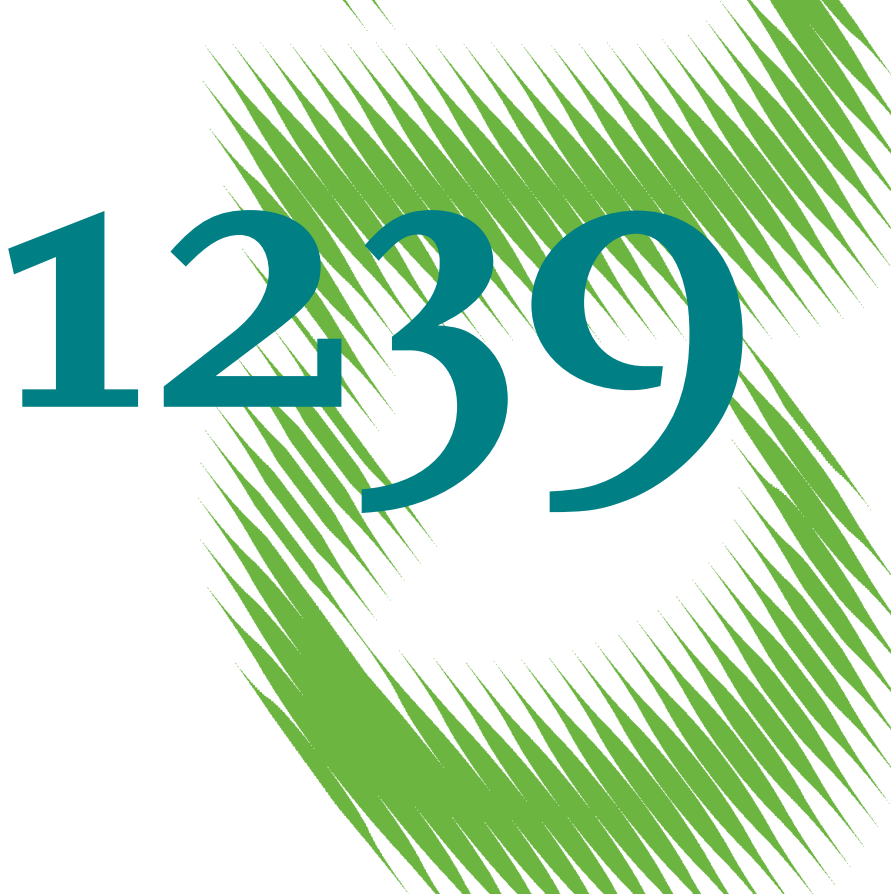

Do Absolute Majorities Spend Less?

Evidence from Germany 
Opinions expressed in this paper are those of the author(s) and do not necessarily reflect views of the institute.

IMPRESSUM

(C) DIW Berlin, 2012

DIW Berlin

German Institute for Economic Research

Mohrenstr. 58

10117 Berlin

Tel. $+49(30) 89789-0$

Fax +49 (30) $89789-200$

http://www.diw.de

ISSN print edition $1433-0210$

ISSN electronic edition 1619-4535

Papers can be downloaded free of charge from the DIW Berlin website:

http://www.diw.de/discussionpapers

Discussion Papers of DIW Berlin are indexed in RePEc and SSRN:

http://ideas.repec.org/s/diw/diwwpp.html

http://www.ssrn.com/link/DIW-Berlin-German-Inst-Econ-Res.html 


\title{
Do absolute majorities spend less? Evidence from Germany
}

\author{
Ronny Freier* Christian Odendahl ${ }^{\dagger}$
}

August 28, 2012

First Version: October 2011

\begin{abstract}
The number of parties in government is usually considered to increase spending. We show that this is not necessarily the case. Using a new method to detect close election outcomes in multi-party systems, we isolate truly exogenous variation in the type of government. With data from municipalities in the German state of Bavaria, we show in regression discontinuity-type estimations that absolute majorities spend more, not less, and increase the property tax rate. We also find weakly significant results for increases in debt. Politically, our results show that the mayor that heads an absolute majority of his own party gains the most, but the party itself does not.
\end{abstract}

Keywords: $\quad$ fiscal spending, local election, absolute majority, municipality data, regression discontinuity

JEL classification: H11, H71, H72, H74

Acknowledgments: We would like to thank Florian Ade, Tim Besley, Tore Ellingsen, Jon Fiva, Olle Folke, Peter Haan, Magnus Johannesson, Juanna Joenson, Henrik Jordahl, Torsten Persson, Per Pettersson-Lidbom, Imran Rasul, Viktor Steiner and David Strömberg for helpful comments and suggestions. Also, we thank seminar participants at the IFN Stockholm (March 2012), the VATT Helsinki (May 2012) and at the University St. Gallen (May 2012). We are greatly indebted to Helke Seitz, Jenny Freier and Heike Hauswald who provided excellent research assistance. Christian Odendahl would like to thank the Hedelius foundation for funding the research visit to the London School of Economics. Ronny Freier gratefully acknowlegdes financial support from the Fritz Thyssen foundation (Project: 10.12.2.092). The usual disclaimer applies.

${ }^{*}$ DIW Berlin.

†Stockholm University 


\section{Introduction}

In proportional election systems, there are typically more than two parties in parliament. This can result in either a coalition government or an absolute majority government of a single party. Does the form of government matter for the level of spending, or debt? This is what we want to investigate empirically.

The theory starts from the question of how groups in society divide a common pool, that is, a situation in which benefits of a certain policy are local, but financing of this policy is global. ${ }^{1}$ The pork barrel model of Weingast, Shepsle, and Johnsen (1981) for instance assumes universalism in the decision process such that each local group can decide independently on how much local spending it receives - financed by a common pool of (global) taxes. In a Nash equilibrium, this results in overspending. ${ }^{2}$

This common pool problem also applies to parties in a coalition government - but the issue here is more subtle: parties of a governing coalition may not internalize the full cost of their targeted spending for the constituencies of other coalition members. Therefore, a coalition government may spend more than a single party government that internalizes the full cost for all its constituencies. Cost in this context means political costs for the other parties in a coalition. These political costs, however, are the result of financial costs of local public goods spending.

Persson, Roland, and Tabellini (2007) provide the most extensive model of what they call an "electoral common pool problem" in coalitions of parties. ${ }^{3}$ Their model starts from first principles, that is, party formation is endogenous and depends on whether the electoral rules are majoritarian or proportional. One key assumption is that voters reward their own party more often than other parties in the coalition. If parties merge to one larger party, the voters cannot discriminate between the groups within the party. Therefore, in a single party government the electoral common pool problem of pleasing your own group at the expense of the other groups in the coalition disappears.

We propose two conceptual frameworks that have the opposite results. First, we argue that indivisibilities of spending can lead absolute majorities to spend more.

\footnotetext{
${ }^{1}$ See Knight (2006) for a recent overview.

${ }^{2}$ Besley and Coate (2003), Lockwood (2002) and Persson and Tabellini (1994) are other examples of the political economics of decentralization and common pool problems using various political models.

${ }^{3}$ Their work is in part inspired by the less formal treatment of these ideas in Bawn and Rosenbluth (2003, 2006).
} 
The reason is that a coalition may not be able to agree on two or more projects and rather implements none. An absolute majority on the other hand may implement its preferred project, which results in higher spending. Second, we draw on the literature about the strategic use of debt by Alesina and Tabellini (1990). ${ }^{4}$ When a government expects to be replaced in the next election with a relatively high probability, it may use its powers to tie the hand of a successor government. A party that won an absolute majority with a small margin may consider it unlikely to be in this unique position in the future. It may therefore spend more on its preferred policy area and incur higher debt, which limits the choices of future governments with different preferences.

Before we discuss our results, we will shortly outline our identification strategy. Empirical research on coalition governments and single party rule needs to overcome the identification problem: the electoral rules, the evolution of a multi-party system and especially the election results are highly endogenous. This is also why older contributions like Roubini and Sachs (1989a,b), that find a positive effect of the number of parties on spending, detect correlations rather than causal relationships. In fact, they themselves point out that the degree of wage indexation and the prevalence of coalition governments is positively correlated. In subsequent research, these problems have been tackled by using control variables, electoral reforms in combination with panel data methods like fixed effects and by instrumenting based on theory.

Bawn and Rosenbluth (2006) use country-level data and rely on control variables and panel data methods for inference. Their results show that the number of parties in government has a large positive effect on the government spending share of GDP in the next year. Persson, Roland, and Tabellini (2007) go one step further: besides using panel data methods, they theoretically motivate a choice of instrumental variables for whether the country in question was headed by a coalition government. Their estimation, based on country-level data, also suggests that coalition governments spend more. Kontopoulos and Perotti (1999) and Perotti and Kontopoulos (2002) show that the number of parties in government may be less important than the number of spending ministers in the cabinet. They use OECD countries and fixed effects specifications to deal with the identification problem. A similar result has also been confirmed on the level of Swiss cantons by Schaltegger and Feld (2009).

Our empirical setup differs from the previous literature. We investigate the hypothesis

\footnotetext{
${ }^{4}$ Another strand in the strategic use of debt literature is Persson and Svensson (1989). They argue that a thrifty government that expects to be replaced may incur debt and lower taxes, to tie the hands of a future spendthrift government. However, we do not distinguish between parties in this setting.
} 
that absolute majorities spend less using municipal election and spending data from the German state of Bavaria. In this data set, we observe more than 2,000 small political units over two election periods in a common proportional election system and a common institutional setting. They do vary in the type of government, however: absolute majority or coalition governments. What is more, roughly $40 \%$ of observations in our sample are governed by an absolute majority. Given the richness of our data, we choose a method more akin to the program evaluation literature: in the spirit of regression discontinuity designs (RDD), we use close elections - that were decisive for a single party or a coalition government - as a source of exogenous variation. Essentially, our design compares absolute majorities that just barely won the last decisive seat to observations with coalition governments, where the largest party in the council barely did not make the threshold to govern alone. The counterfactual to an absolute majority is therefore a coalition government of which the large party is likely to be a part of. ${ }^{5}$

Close elections are increasingly common as a source of exogenous variation in empirical political economics, starting with Pettersson-Lidbom (2008) on Swedish municipal councils and Lee (2008) on incumbency of US House representatives. ${ }^{6}$ However, two recent studies (Caughey and Sekhon (2011) and Grimmer, Hersh, Feinstein, and Carpenter (2011)) have shown that the exogeneity of close election outcomes should not be taken for granted. We will provide a battery of tests in order to assess the validity of our design. ${ }^{7}$

Detecting close election outcomes in a proportional election system is far from easy, even for outcomes that are seemingly simple like the $50 \%$ seat threshold in a municipal council. The reason is that seats are distributed according to a complex rule, and a vote share as low as $41 \%$ may be enough to win $50 \%$ of the seats. We identify close election outcomes using a new method, where we simulate a slightly perturbed election and observe changes in the seat allocation. Cases in which the seat allocation changes

\footnotetext{
${ }^{5}$ We only consider those absolute majorities in which the mayor is from the largest party. This allows us to abstract from legislative bargaining considerations. It also makes it more likely that the largest party is part of a governing coalition in cases where it cannot win an absolute majority because the mayor is also from that party.

${ }^{6}$ Other examples include Lee, Moretti, and Butler (2004) on the US House, Ferreira and Gyourko (2009) and Gerber and Hopkins (2011) on US mayors, Folke and Snyder (2012) on gubernatorial midterm slumps as well as DiNardo and Lee (2004) and Lee and Mas (2012) on union elections.

${ }^{7}$ There have also been critical studies on the local level, for instance Vogl (2011) that uses larger municipalities in the US. Our design on the other hand is supported by studies on German mayoral elections (Freier (2011)) and on German council elections (Freier and Odendahl (2011)). Both papers show the validity of their respective RDDs.
} 
often in repeated simulations are considered close. ${ }^{8}$

We find three key results. First, absolute majorities spend more, not less. This effect is particularly strong for non-CSU parties, that is, parties other than the dominant party in Bavaria. Second, we find that property tax rates increase and also some indication that debt increases. Finally, we show that the party that governs with an absolute majority derives no political benefits from its power. The mayor on the other hand, that is from the same party and therefore heads this absolute majority, does gain politically.

The paper is organized as follows: section 2 lays out two conceptual frameworks for spending decisions of absolute majority governments, section 3 discusses the institutional background and the data, the 4th section contains the empirical strategy, and section 5 the results. After we discuss the robustness and validity of our design in section 6 , section 7 concludes.

\section{Two conceptual frameworks}

Contrary to the electoral common pool problem laid out in Persson, Roland, and Tabellini (2007), we present two conceptual frameworks for why single party governments may in fact spend more. One is based on indivisibilities of spending, the second on the strategic use of debt.

If spending is a discrete choice, that is, projects are of a given size like a new road or a kindergarten, how many projects will be implemented? In a coalition government, the agenda setter has to offer other coalition members at least their reservation utility. Taxation without their preferred project will be lower than their reservation utility, so the agenda setter has to offer each coalition member their preferred project. The choice for the agenda setter is therefore whether to implement the projects of all coalition members (including her own), or none. Depending on the valuation of the projects, the outcome could be that no project is implemented. If, on the other hand, there is an absolute majority government, the same choice is whether to implement her preferred project or not. Under reasonable assumptions about the value of that project, it will be set up and an absolute majority spends more than a coalition government. This model is probably more relevant on the local than on the federal level, considering the type of spending decisions. In this paper, we only consider

\footnotetext{
${ }^{8}$ We use a similar method in Freier and Odendahl (2011).
} 
the local level and therefore expect to see higher spending by absolute majorities if indivisibilities are an important issue. ${ }^{9}$

The second idea is related to our empirical strategy: if a party has barely won the power of absolute majority - potentially through a popularity shock - it might assign a rather high probability to losing this absolute majority in the next election. ${ }^{10}$ In our setting, this is a reasonable assumption as we empirically look only at close election outcomes as an exogenous source of variation, and thus very close absolute majorities. Then a classic story about the strategic use of debt unfolds, based on Alesina and Tabellini (1990): ${ }^{11}$ Parties differ in their preference for two distinct public goods, comparable to the first framework above. If the chances of one party to be re-elected are relatively small, it will overspend on its preferred public good, and finance this with higher debt to tie the hands of the successor government. This new government will have to strike a balance between the marginal cost of extra spending, given a now higher debt level, and the marginal benefit of its preferred policy. ${ }^{12}$

The empirical predictions that follow from both conceptual frameworks combined are that the absolute majorities that we identify spend more for two reasons: First, parties may favor different public goods and therefore overspend to tie the hands of the next government. Second, there might be indivisibilities in spending, which leads an absolute majority to implement their project, but forces a coalition government to implement none. The next section provides some background on the elections and the data before we move on to the empirical specification and the results.

\section{Institutional background and data}

We use data from municipal elections in the German state of Bavaria in the south-east of Germany. ${ }^{13}$ All municipalities in Germany use some form of proportional elections

\footnotetext{
${ }^{9} \mathrm{~A}$ similar argument has been made by Tsebelis (1995). He suggests that policy change is mainly determined by how many veto players are present. He recognizes that multiple parties in a coalition government each possess veto power. A larger number of veto players in his model - in our case a coalition government versus an absolute majority - will be connected with less change in policy, and hence less investment projects that are realized.

${ }^{10}$ In fact, we find that having an absolute majority on the margin has no positive effect on the probability of having one in the next election.

${ }^{11}$ Persson and Tabellini (2002) provide a basic exposition of the strategic use of debt, while Pettersson-Lidbom (2001) offers an empirical treatment and a good overview.

${ }^{12}$ The intuition is that servicing a higher debt load requires higher (distortionary!) taxes, so a higher debt burden c.p. lowers public goods spending.

${ }^{13}$ Bavaria consists of more than 2,000 municipalities and has a population of 12.5 million on an area of $70^{\prime} 500 \mathrm{~km}^{2}$ (6'775 square miles), roughly the size of Switzerland and Belgium combined. See Bayerisches Landesamt fuer Statistik und Datenverarbeitung (2011).
} 
for their council, and Bavaria is no exception. The dominant party is the Christian Social Union (CSU), a center-right party that has dominated Bavarian politics since the end of World War II. Absolute majorities are therefore common in Bavarian local politics, but they also exist for non-CSU parties.

A local government in Bavaria consists of an elected mayor and a legislative body, the town council. The mayor is the head of the administration and also a voting member of the council. On average, the municipal authorities manage a yearly budget of about 1570 euro per capita. The revenue of a municipality consists of its own taxes (two property taxes, one business or trade tax), shares of the revenue of state and federal taxes, as well as allocated funds from higher tiers of government that the municipality administers, e.g. for public schools or social services. Other main areas of municipal spending are general administration, public order, infrastructure, cultural institutions and public transport. Although the division of tasks between the different tiers of government is complex in Germany, the municipalities do have discretion in their budget.

In Bavaria, we have a homogeneous institutional setting and a relatively high number of absolute majorities. What is more, we have consistent information about the mayor which is an important factor in absolute majorities as they are usually from the largest party and a voting member of the council. The descriptives statistics are presented in table 1 . There are absolute majorities in $42 \%$ of municipalities, with a median number of parties of three. Further descriptive statistics on the outcome variables are given in table 5 in the appendix. The variation is relatively high, particularly for investment spending and debt. The tax rates are given as multipliers that the municipality can set, based on a federal law. The multipliers in theory range from 0 to 800 , but are usually in the range of $300-350 .^{14}$

\footnotetext{
${ }^{14}$ Bundesfinanzministerium (2012) and Bundesbank (2007) contain the details (in German). Information in English can be found in Bundeszentralamt fuer Steuern (2012).
} 
Table 1: Sample description

\begin{tabular}{|c|c|c|c|c|c|}
\hline & (1) & $(2)$ & $(3)$ & $(4)$ & $(5)$ \\
\hline & Mean & Std. dev & Median & $25 \%$ ile & $75 \%$ ile \\
\hline Average population & 5867.3 & 30659.3 & 2710.5 & 1544 & 5134 \\
\hline Council size & 15.7 & 5.84 & 14 & 12 & 20 \\
\hline Number of parties & 3.67 & 1.59 & 3 & 3 & 4 \\
\hline Vote share of strongest party & 49.20 & 17.44 & 45.23 & 38.18 & 54.86 \\
\hline $\begin{array}{l}\text { Vote share of strongest party } \\
\text { (if no. parties } \geq 3 \text { ) }\end{array}$ & 41.3 & 8.6 & 41.2 & 35.8 & 46.7 \\
\hline Vote share of 2 nd strongest party & 28.53 & 10.27 & 29.11 & 23.53 & 34.89 \\
\hline Share of absolute majorities & 0.421 & 0.494 & 0 & 0 & 1 \\
\hline
\end{tabular}

Notes: The table shows the descriptive statistics for the sample. We present sample means, standard deviations, median as well as the $25 \%$ and the $75 \%$ percentiles of the distributions for the variables indicated in the left column. In total, we observe 2051 Bavarian municipalities for 2 election terms (1996-2002, 2002-2008). Source: Own calculations, based on the data provided by the Bavarian statistical office.

\section{Empirical strategy}

In order to estimate the effect of absolute majorities on spending and tax decisions, we need to overcome the endogeneity problem that plagues many observational study in political economics: election outcomes are not random. They reflect political preferences of the constituencies and change over time. However, we know that there are certain thresholds at which political power changes discontinuously. These discontinuities offer an excellent opportunity to extract exogenous variation in a political variable. Our empirical strategy is therefore based on regression discontinuity-type estimations. $^{15}$

In our context, we are interested in the threshold at which an absolute majority

\footnotetext{
${ }^{15}$ Apart from the RDD literature in political economics, there are many examples outside of it. Thistlethwaite and Campell (1960) is an early application outside of economics, and van der Klaauw (2002) one of the first within economics. See Hahn, Todd, and van der Klaauw (2001) and Imbens and Lemieux (2008) for overviews of the method, and Cook (2008) for an interesting historical exposition.
} 
governs the council. In other words, we want to compare cases in which a party barely won an absolute majority to cases in which it barely did not and a coalition government had to be formed. ${ }^{16}$ To abstract from legislative bargaining between the mayor and the majority of the council, we only consider those absolute majorities in the council that also included the mayor from the same party.

For example, if we have a council with 12 members, in which the mayor is the 13th member and is of party A, we compare cases in which party A just lost the 6th seat, to cases in which it just won the 6th seat and - combined with the mayor - has 7 out of 13 seats. Our relevant threshold is then the $50 \%+1$ seat majority in the council, given a mayor from the same party. Assigning treatment therefore seems straightforward. An RDD, however, requires us to either come very close to the threshold or - better: and - control for deviations from the threshold by including a control function. None of this is straightforward in our setting, unfortunately.

It may seem that the $50 \%+1$ seat threshold roughly translates into the $50 \%$ vote share threshold, but it is much more complicated than that. In each proportional election system, there is a seat allocation rule that translates a large number of votes into a small, discrete number of seats. ${ }^{17}$ Whether a party receives this last seat to have an absolute majority therefore depends not only on its own votes, but also on the distribution of votes among the other parties. In some cases in our data, $41 \%$ of the votes was enough to secure half the seats, whereas in other cases it took up to $48 \%{ }^{18}$

The so-called forcing variable of our RDD is therefore the whole vector of votes. ${ }^{19}$ To identify a close absolute majority therefore requires to know how far from the decisive seat change we are for the largest party. We shortly elaborate on how we accomplish that.

In order to determine which absolute majorities were close, we repeatedly perturb the

\footnotetext{
${ }^{16}$ We only consider observations that had 3 or more parties.

${ }^{17}$ The municipal elections in Bavaria use the d'Hondt method. In this method, the total number of votes is divided by the total number of seats. This results in the "price" of one seat. After the votes of each party are divided by this price, we receive the exact distribution of seats. In a next step, all numbers are rounded down to get the integer. Since this will leave at least one seat unoccupied, the "price" is lowered slightly, until this procedure distributes all seats.

${ }^{18}$ The method used in Bavaria favors larger parties. This is why no party needed $50 \%$ of the votes to command an absolute majority.

${ }^{19}$ This is different from the recent literature (e.g. Imbens and Zajonc (2011)) on multiple variables in an RDD. In our setting, there are not only multiple variables that determine the threshold, but these multiple variables interact with each other in complex ways.
} 
votes of all parties in a municipality and observe whether the seat allocation changes. ${ }^{20}$ We use a normally distributed random variable for each party to perturb the votes. These random variables have expectation zero and variance $\left(k v_{j, i}\right)^{2}$, where $v_{j, i}$ are the votes of party $j$ in municipality $i$. The factor $k$ therefore scales the standard deviation such that it is a percentage share of the votes for this party. We will use $k=1 \%$ and $k=2 \%$. If the seats change often, we consider this allocation close. We define "often" as $1 / 6$ of the time. ${ }^{21}$

Including a control function is important in RDDs unless the amount of data allows us to get arbitrarily close to the threshold. ${ }^{22}$ In our setting, the forcing variables are the votes of all parties and the council size, combined in a complex formula. There is no natural control function to include and the treatment can occur at quite different points on this function. If we used all observations and relied on the control function to precisely filter out all influences other than the type of government, we would probably fail. We therefore minimize our reliance on the control function and use only our carefully selected close elections as a source for our identification. When we do use a control function of the vote share of the strongest party, we estimate it over the whole range of observations, and specify it flexibly on both sides of our threshold.

Our regression takes the following form:

$$
y_{i}=\alpha+\beta D_{i}+\gamma c_{i}+f\left(v_{i}\right)+\mathbf{X}_{i} \delta+e_{i},
$$

where $y_{i}$ is the outcome variable (spending, taxes or debt), $D_{i}$ is a dummy for whether a party has a close absolute majority, and $c_{i}$ is a dummy for whether the seat that decided about the absolute majority was close. The control function $f\left(v_{i}\right)$ of the vote share of the strongest party is quadratic, and interacted with a dummy variable $T_{i}$ that denotes all absolute majorities. This way, we allow for different control functions on both sides of our threshold. Note that there is a difference between $T_{i}$ and $D_{i}$ : $D_{i}$ only marks those absolute majorities that were close, whereas $T_{i}$ is equal to one for all absolute majorities. $\mathbf{X}_{i}$ is a set of controls that include population, council

\footnotetext{
${ }^{20}$ Folke (2010) uses an analytical method to determine, based on the election rules, the minimal vote share that was required for a seat change. Our approach, while leading to very similar results, is easier to implement, and lends itself naturally to many different settings.

${ }^{21}$ The reason is that for normally distributed variables roughly $1 / 3$ of the probability mass lies outside of one standard deviation and we observe seat changes almost always in just one direction during the perturbations. So a "close" outcome that changes more than $1 / 6$ th of the time required on average a vote change of about one standard deviation, $\left(k v_{j}\right)$, even though in specific perturbed simulations, it might have been more (or less).

${ }^{22}$ See Hahn, Todd, and van der Klaauw (2001) for a formal treatment of the bias that otherwise occurs.
} 
size, year dummies, and a dummy for whether the CSU is taking part in the election. In some specifications, it also includes a lagged outcome variable. In essence, we are using all observations that were not close only to add precision to the estimation of the control function and the other control variables. The identification of the coefficient of interest, $\beta$, is based on our close absolute majorities. Note that we only use observations that had three or more parties to ensure that we compare observations with absolute majorities to those that had a coalition government.

Adding lagged dependent variables as a regressor is a delicate issue. On the one hand, it is not necessary to include baseline covariates - of which the lagged dependent variable is a part - in a perfect experiment with sufficient amounts of data. It is often done nonetheless because it has the potential to reduce sampling errors if the amount of data is limited. On the other hand, lagged dependent variables introduce a potential bias: if the error term is serially correlated, it will be correlated with the lagged dependent variable and may therefore bias the estimated coefficient of interest as well.

Our empirical specification passes the validity tests in section 6 . However, our main concern is that the remaining differences in pre-determined outcome variables may obscure the true effect of absolute majorities - especially since the number of observations is low the closer we come to the threshold. Therefore, controlling for the lagged dependent variable in an arguably very good experiment has the potential to reduce sampling errors and correct for underlying differences that occurred by chance. ${ }^{23}$

We also show the results of a simple OLS specification of the following form:

$$
y_{i}=\alpha+\beta T_{i}+\mathbf{X}_{i} \gamma+e_{i}
$$

As an intermediate step from OLS toward our RDD, we limit the OLS sample to those observations that were just one seat above or below the absolute majority threshold.

\section{Results}

Table 2 contains our main results, where each coefficient represents a separate regression. Columns (1) and (2) are based on the OLS equation (2), where the second specification restricts the sample to those cases in which a party was exactly one

\footnotetext{
${ }^{23}$ This is also why Lee and Lemieux (2009) recommend to use baseline covariates, including lagged dependent variables, in an RDD and in the validity tests.
} 
seat above or below the threshold for an absolute majority. The results in columns (1) show that an absolute majority is associated with slightly higher spending, even though we do not recommend to interpret these results as causal relationships for the reasons given above. The results in column (2) give a better impression of a causal effect as we limit our attention to reasonably close election outcomes. The effects are economically large and highly significant: absolute majorities seem to spend more.

Columns (3)-(6) contain the RDD results based on regression (1) that we can confidently interpret as causal. In the first two columns of these, we set our closeness parameter $k$ equal to $2 \%$, in the remaining two columns, we use $1 \%$. In columns (4) and (6) we include our quadratic control function of the vote share of the strongest party. The results including the lagged dependent variable show positive and significant effects: absolute majorities spend more, and substantially so considering that the average spending is 1570 euro per capita, with a standard deviation of roughly 600. Excluding the lagged dependent variable lowers the precision of our estimates, but they remain in the same ballpark.

Table 2: Spending of absolute majorities

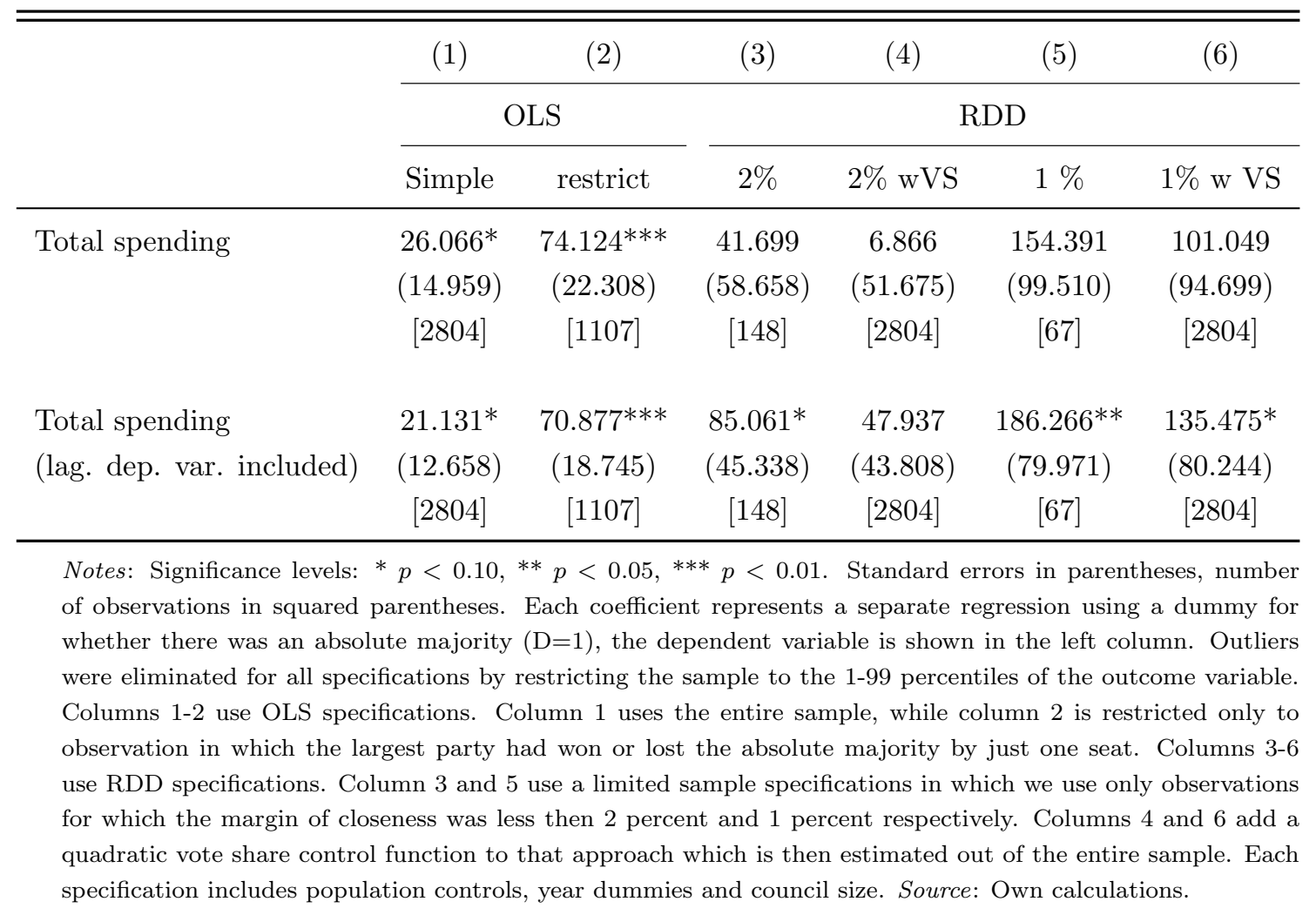

If we examine our results in a little more detail, we find which parties are mainly 
responsible for this increase in spending. Table 3 is set up in exactly the same way as table 2, but we only look at non-CSU parties, that is, only those observations in which parties other than the dominant party in Bavaria were close to winning or losing an absolute majority. As the table shows, these effects are larger and of higher significance than the overall estimates above, indicating that the non-CSU parties are mainly driving the effects.

Table 3: Spending of absolute majorities (only non CSU)

\begin{tabular}{|c|c|c|c|c|c|c|}
\hline & (1) & $(2)$ & $(3)$ & $(4)$ & $(5)$ & (6) \\
\hline & \multicolumn{2}{|c|}{ OLS } & \multicolumn{4}{|c|}{ RDD } \\
\hline & Simple & restrict & $2 \%$ & $2 \% \mathrm{wVS}$ & $1 \%$ & $1 \% \mathrm{w} \mathrm{VS}$ \\
\hline Total spending & $\begin{array}{c}61.047^{* *} \\
(24.657) \\
{[1253]}\end{array}$ & $\begin{array}{c}124.371^{* * * *} \\
(37.104) \\
{[432]}\end{array}$ & $\begin{array}{c}88.239 \\
(87.961) \\
{[51]}\end{array}$ & $\begin{array}{c}123.346 \\
(88.071) \\
{[1253]}\end{array}$ & $\begin{array}{c}362.338^{* * *} \\
(115.129) \\
{[21]}\end{array}$ & $\begin{array}{c}358.737 * * \\
(176.502) \\
{[1253]}\end{array}$ \\
\hline $\begin{array}{l}\text { Total spending } \\
\text { (lag. dep. var. included) }\end{array}$ & $\begin{array}{c}46.038^{* *} \\
(21.645) \\
{[1253]}\end{array}$ & $\begin{array}{c}126.359^{* * *} \\
(32.861) \\
{[432]}\end{array}$ & $\begin{array}{c}142.587^{*} \\
(74.657) \\
{[51]}\end{array}$ & $\begin{array}{c}148.529 * \\
(77.267) \\
{[1253]}\end{array}$ & $\begin{array}{c}362.435^{* * *} \\
(113.635) \\
{[21]}\end{array}$ & $\begin{array}{c}341.121^{* *} \\
(154.937) \\
{[1253]}\end{array}$ \\
\hline \multicolumn{7}{|c|}{$\begin{array}{l}\text { Notes: Significance levels: }{ }^{*} p<0.10,{ }^{*} p<0.05,{ }^{* *} p<0.01 \text {. Standard errors in parentheses, number of } \\
\text { observations in squared parentheses. Each coefficient represents a separate regression using a dummy for whether } \\
\text { there was an absolute majority }(\mathrm{D}=1) \text {, the dependent variable is shown in the left column. Outliers were eliminated } \\
\text { for all specifications by restricting the sample to the } 1-99 \text { percentiles of the outcome variable. Columns } 1-2 \text { use OLS } \\
\text { specifications. Column } 1 \text { uses the entire sample, while column } 2 \text { is restricted only to observation in which the largest } \\
\text { party had won or lost the absolute majority by just one seat. Columns } 3-6 \text { use RDD specifications. Column } 3 \text { and } 5 \\
\text { use a limited sample specifications in which we use only observations for which the margin of closeness was less then } \\
2 \text { percent and } 1 \text { percent respectively. Columns } 4 \text { and } 6 \text { add a quadratic vote share control function to that approach } \\
\text { which is then estimated out of the entire sample. Each specification includes population controls, year dummies and } \\
\text { council size. Source: Own calculations. }\end{array}$} \\
\hline
\end{tabular}

So far we have only considered overall spending as the outcome variable. In table 6 in the appendix, we also look at other fiscal variables like taxes, debt, and some subsets of overall spending. ${ }^{24}$ Although debt is higher in all specifications, the effects are imprecisely estimated which is not surprising given the higher overall variability in debt shown in the descriptive statistics in table 5 in the appendix. What is striking is the effect on taxes: rather than using debt alone to finance the increase in spending, absolute majorities use concurrent taxes as well. The results for investment spending

\footnotetext{
${ }^{24}$ Note that in this table, we have left out the OLS regressions and only show the main specification including the lagged outcome variable. Each coefficient again represents a separate regression.
} 
show a consistent increase, but the high variability of this type of spending does not allow for a very precise estimation.

Next, we turn from policy effects to political outcomes. Table 4 contains the results, and each coefficient represents a separate regression. ${ }^{25}$ There is no significant effect on the vote share of the absolute majority party, nor on its probability to obtain this position again. However, the mayor does benefit considerably: governing with the support of an absolute majority from her own party adds $14-21 \%$ to her probability of winning the mayoral election next time.

Table 4: Electoral effects on subsequent mayor and council elections

\begin{tabular}{lccc}
\hline \hline & $(1)$ & $(2)$ & $(3)$ \\
\cline { 2 - 4 } & \multicolumn{3}{c}{ RDD } \\
\cline { 2 - 4 } & 3 percent & 2 percent & 1 percent \\
\hline Prob. of winning the mayor office $(\mathrm{t}+1)$ & $0.140^{* *}$ & $0.184^{* *}$ & $0.207^{*}$ \\
& $(0.063)$ & $(0.074)$ & $(0.116)$ \\
Prob. of absolute majority $(\mathrm{t}+1)$ & & & \\
& -0.003 & 0.017 & 0.160 \\
& $(0.068)$ & $(0.076)$ & $(0.112)$ \\
Vote share in next election $(\mathrm{t}+1)$ & & & $0.035^{*}$ \\
& 0.014 & 0.002 & $0.019)$ \\
\hline
\end{tabular}

Notes: Significance levels: ${ }^{*} p<0.10,{ }^{* *} p<0.05,{ }^{* * *} p<0.01$. Standard errors in parentheses. Each coefficient represents a separate regression using a dummy for whether there was an absolute majority $(D=1)$, the dependent variable is shown in the left column. Column 1 uses a limited sample specifications in which we use only observations for which the margin of closeness was less then 3 percent. Column 2 and columns 1 limited that margin to 2 and 1 percent respectively. A vote share control function is not used here, because we collected data on the political outcome variables only for the observations in the close margin samples. Each specification includes population controls, year dummies and council size. Source: Own calculations.

The results presented so far have a clear message: absolute majorities spend more, not less, in our setting. However, we should note that our estimates are local in two respects. First, they are based on close absolute majorities only. Our results may therefore not apply to absolute majorities that were not close. ${ }^{26}$ Second, we are

\footnotetext{
${ }^{25}$ Note that we only use the close samples without a control function, and therefore add the sample with $k=3 \%$ as well. The reason is that we only manually added the political outcome variables for the close absolute majority elections, and not for all 2804 observations.

${ }^{26}$ On the other hand, the OLS results - especially those that we limit to being one seat away from the threshold - also point toward higher spending of absolute majorities. Our causal effects may therefore be less local than the empirical design suggests.
} 
looking at local spending that may be different from spending on higher tiers of government. We also find evidence that debt increases as well, albeit often insignificantly so, which may support a strategic use of debt story outlined above. The increase in investment spending is also insignificant, but consistently positive, which shows that indivisibilities of spending may be part of the reason. Given the high variation in debt and investment spending, our imprecisely estimated effects therefore support both conceptual frameworks above.

In additional tests in section 6, we find that absolute "super-majorities", that is, absolute majorities that could govern even without the mayor, do not increase spending. Part of the reason could be that the mayor is the driving force of the spending increases that we find, which is supported by the political effects: only the mayor benefits from an absolute majority. Another reason could be that the absolute majority was stable in the sense that the party expects to govern this municipality with an absolute majority in the future as well. In other words, there is no need for the strategic use of debt in this context.

\section{Robustness and Validity}

In this section, we offer tests for the validity of our design and the robustness of the results. We start with the latter. In table 7 in the appendix, we show how alternative specifications in the vote share control function of the strongest party affect our estimates. In the first two columns, we vary the order of the control function, in columns (3) and (4) we include the second strongest party's vote share, the last two remove two conditions that we imposed: that the control function differs on both sides of the threshold, and that we only consider observations in which the mayor is from the strongest party. ${ }^{27}$ All six columns show that our results are stable, even though they lose significance if we consider all parties. For non-CSU parties, the effects are almost unchanged.

Turning to the validity of our results, we first show a series of four graphs (in the appendix) before turning to a regression-based test on pre-determined variables. We end the section with a test at other thresholds.

Figure 1 shows the distribution of close elections for a wide range of choices of our closeness variable $k .^{28}$ Each bar represents the number of observations that were added

\footnotetext{
${ }^{27}$ Note that we keep this mayor restriction in place for the close observations that identify the effect, even in column (6). We only lift this condition for the estimation of the control function.

${ }^{28}$ So far, we have only used $k=1 \%$ and $k=2 \%$.
} 
by extending the definition of closeness by .2 percentage points, for example, by using $k=1.2 \%$ instead of $k=1 \%$. It is depicted as the frequency graphs for usual RDDs, that is, where the threshold is known and fixed, and the frequency of observations is compared on both sides of the threshold. ${ }^{29}$ The units on the horizontal axis should therefore not be taken literally. What emerges from the frequency distribution is that the variations on either side are small, and not a source of concern for our design.

In a related but different figure 2 in the appendix, we show the distribution of one major part of our forcing vector: the vote share of the strongest party. The figure is separated by the value of $k$ and whether the close election result led to a coalition government or an absolute majority. Of course, we expect the vote share to be on average $k \%$ points higher in the absolute majority sample, given our perturbation design. There is no notable difference in the distributions. The final two graphs in figures 3 and 4 show the distribution of the vote share of the dominant Bavarian party, the CSU, and the distribution of the population size, both separated by our treatment variable. In both variables, the distribution is very similar.

In our design, we use the averaged spending over the government term as the outcomes variable. If, on the other hand, we use variables as the outcome that should not be affected - the value of last term's spending, or the council size - we should not find any effects. The results of this validity test for each variable separately are shown in table 8 in the appendix. ${ }^{30}$

The political and descriptive variables (population and council size, number of parties, absolute majority in $t-1$ ) show no tendency in one or the other direction. These variables therefore support our design. The fiscal variables during the last government term are presented in panel two of table 8. The fact that total spending is (insignificantly) smaller in the last government term where there is an absolute majority in the next is a source of concern for our results. This is also why we include lagged dependent variables, in order to minimize potential sampling error. We therefore conclude that our results are still valid in the presence of the slightly negative spending estimate with which the absolute majorities started their term.

Other fiscal variables show no clear tendency in this test: debt, personnel and invest-

\footnotetext{
${ }^{29}$ The formal test of frequency after McCrary (2008) is possible in our design as well, but computationally demanding.

${ }^{30}$ The only difference to the main specification above is that we do not include a lagged dependent variable (from t-2). We also conducted a seemingly unrelated regression (SUR) using all these variables combined (see Lee and Lemieux (2009) for details). The test for significance of absolute majority in this system of equations was insignificant (results not shown).
} 
ment spending, as well as the main property tax B, for which we find significant effects in the original results, are all balanced on average. The trade tax and the secondary property tax do seem to vary slightly, but since we cannot find any results in our main estimations - with the lagged variable included - they are not of concern for our main results. Overall, the pre-determined test confirms the validity of our design.

Finally, we apply our empirical design to two other thresholds. The first is where we artificially declare those parties the winner of an absolute majority that have one seat less than they should have. For example, in a council of 13 (including the mayor), we have so far considered those observations in which the strongest party was close to winning or losing the 7th seat. Now, we compare those in which the strongest party was close to winning or losing the 6 th seat. While we are tempted to call this a placebo test, it is not a real placebo as the seat distribution does change. However, the results in the first panel of table 9 show that this low dose of political change has no effect on spending, contrary to the high dose of moving from a coalition government to an absolute majority.

The second test is similar: we compare those observations in a council of, say, 13 in which the strongest party was close to winning or losing the 8th seat. Such absolute "super-majorities" therefore do not depend on the mayor (that we still restrict to come from the same party). This test is therefore not a placebo test either, as the power of the mayor may change. On the other hand, we are comparing absolute majorities that were not very close to losing their status, which may impact their policy setting as well. The results are presented in the second panel of table 9 . They show that the effects are insignificant, but have a clearly negative tendency. While that does not invalidate our design, it does suggest, that either the mayor may be a decisive factor for whether an absolute majority spends more or that a highly contested absolute majority may act differently than a less contested one. ${ }^{31}$

\section{Conclusion}

The purpose of this paper is to empirically investigate whether absolute majorities spend less, as the literature on the electoral common pool problem and the existing empirical evidence suggests. Our regression discontinuity-type estimation procedure allow us to carefully isolate close elections in order to use truly exogenous variation in the form of government.

\footnotetext{
${ }^{31}$ The obvious solution is to compare absolute majorities in which the mayor comes from another party. This, however, is impossible to test empirically as such cases are very rare.
} 
We find that in our setting - local spending in municipalities in the German state of Bavaria - the opposite is true: absolute majorities spend more overall. This effect is stronger for parties other than the dominant party in Bavaria. We also find indications that absolute majorities increase debt and investment spending, and a significantly positive effect on taxes. Finally, we show that the political benefits of an absolute majority in the next election accrue mostly to the mayor, not to the party as a whole.

We propose two conceptual frameworks for thinking about this result. The first is based on indivisibilities of local spending, the second on the strategic use of debt. Contrary to the literature on coalition governments and spending, they imply that absolute majorities in fact spend more. We find some supportive evidence for both frameworks.

\section{References}

Alesina, A., And G. Tabellini (1990): "A Positive Theory of Fiscal Deficits and Government Debt," Review of Economic Studies, 57(3), 403-14.

Bawn, K., And F. Rosenbluth (2003): "Coalition Parties versus Coalitions of Parties: How Electoral Agency Shapes the Political Logic of Costs and Benefits," Presented at the 2003 Annual Meeting of the American Political Science Association.

(2006): "Short versus Long Coalitions: Electoral Accountability and the Size of the Public Sector," American Journal of Political Science, 50(2), 251-265.

BAyERisches LANDEsamt Fuer Statistik Und Daten-
verarbeitung "Genesis Online Database," https://www.statistikdaten.bayern.de/genesis/online/logon, June 9.

Besley, T., and S. CoAte (2003): "Centralized versus decentralized provision of local public goods: a political economy approach," Journal of Public Economics, $87(12), 2611-2637$.

Bundesbank (2007): "Zur Entwicklung der Gemeindefinanzen seit dem Jahr 2000," Monatsbericht.

Bundesfinanzministerium (2012): "Die Steuereinnahmen der Gemeinden, Stand Januar 2012," Brochure. 
Bundeszentralamt fuer Steuern (2012): "Trade Tax (Gewerbesteuer)," Internet document, www.steuerliches-info-center.de.

Caughey, D. M., and J. S. Sekhon (2011): "Regression-Discontinuity Designs and Popular Elections: Implications of Pro-Incumbent Bias in Close U.S. House Races," Working Paper.

Cook, T. D. (2008): "Waiting for Life to Arrive: A history of the regressiondiscontinuity design in Psychology, Statistics and Economics," Journal of Econometrics, 142(2), 636 - 654, jce:title ¿The regression discontinuity design: Theory and applicationsi/ce:title . $_{\text {. }}$

DiNardo, J., And D. S. LeE (2004): "Economic Impacts of New Unionization on Private Sector Employers: 1984 - 2001.," Quarterly Journal of Economics, 119 (4), $1383 ? 1441$.

Ferreira, F., And J. Gyourko (2009): "Do Political Parties Matter? Evidence from U.S. Cities," Quarterly Journal of Economics, 124(1), 399-422.

Folke, O. (2010): "Shades of Brown and Green: Party Effects in Proportional Election Systems," Working Paper, IIES.

Folke, O., And J. M. Snyder (2012): "Gubernatorial Midterm Slumps," .

Freier, R. (2011): "Incumbency as the major advantage - The scopes and determinants of the electoral advantage for incumbent mayors," available as DIW working paper soon.

Freier, R., and C. Odendahl (2011): "Do Parties Matter? Estimating the effect of political power in multi-party systems," Unpublished manuscript.

Gerber, E. R., And D. J. Hopkins (2011): "When Mayors Matter: Estimating the Impact of Mayoral Partisanship on City Policy," American Journal of Political Science, 55(2), 326-339.

Grimmer, J., E. Hersh, B. Feinstein, and D. Carpenter (2011): "Are Close Elections Random?," Working Paper.

Hahn, J., P. Todd, and W. van Der KlaAuw (2001): "Identification and Estimation of Treatment Effects with a Regression-Discontinuity Design," Econometrica, 69, 201-209. 
Imbens, G., And T. Lemieux (2008): "Regression Discontinuity Designs: A Guide to Practice," Journal of Econometrics, 142, 615-635.

Imbens, G., And T. Zajonc (2011): "Regression Discontinuity Design with Multiple Variables," mimeo.

Knight, B. (2006): "Common Tax Pool Problems in Federal Systems," in Democratic Constitutional Design and Public Policy: Analysis and Evidence, ed. by R. Congleton, and B. Swedenborg, pp. 229-250. MIT Press.

Kontopoulos, Y., and R. Perotti (1999): "Government Fragmentation and Fiscal Policy Outcomes: Evidence from OECD Countries," in Fiscal Institutions and Fiscal Performance, ed. by J. M. Poterba, and J. von Hagen, NBER Chapters, pp. 81-102. National Bureau of Economic Research, Inc.

LEE, D. S. (2008): "Randomized experiments from non-random selection in U.S. House elections," Journal of Econometrics, 142, 675 - 697.

Lee, D. S., And T. Lemieux (2009): "Regression Discontinuity Designs in Economics," Working Paper 14723, National Bureau of Economic Research.

LeE, D. S., ANd A. MAs (2012): "Long-Run Impacts of Unions on Firms: New Evidence from Financial Markets, 1961-1999," .

Lee, D. S., E. Moretti, and M. Butler (2004): "Do Voters Affect or Elect Policies? Evidence from the U.S. House," Quarterly Journal of Economics, 119(3), $807-859$.

Lockwood, B. (2002): "Distributive Politics and the Costs of Centralization," Review of Economic Studies, 69(2), 313-37.

MCCRARY, J. (2008): "Manipulation of the running variable in the regression discontinuity design: A density test," Journal of Econometrics, 142(2), 698 - 714.

Perotti, R., And Y. Kontopoulos (2002): "Fragmented fiscal policy," Journal of Public Economics, 86(2), 191 - 222.

Persson, T., G. Roland, and G. Tabellini (2007): "Electoral Rules and Government Spending in Parliamentary Democracies," Quarterly Journal of Political Science, 2(2), 155-188. 
Persson, T., And L. E. O. Svensson (1989): "Why a Stubborn Conservative Would Run a Deficit: Policy with Time-Inconsistent Preferences," The Quarterly Journal of Economics, 104(2), 325-45.

Persson, T., And G. TABellini (1994): "Does centralization increase the size of government?," European Economic Review, 38(3-4), 765-773.

(2002): Political Economics: Explaining Economic Policy. The MIT Press.

Pettersson-Lidbom, P. (2001): “An Empirical Investigation of the Strategic Use of Debt," Journal of Political Economy, 109(3), 570-583.

(2008): "Do Parties Matter for Economic Outcomes? A RegressionDiscontinuity Approach," Journal of European Economic Association, 6(5), 10371056 .

Roubini, N., And J. Sachs (1989a): "Government Spending and Budget Deficits in the Industrial Countries," Economic Policy, 4(8), pp. 99-132.

Roubini, N., and J. D. Sachs (1989b): "Political and economic determinants of budget deficits in the industrial democracies," European Economic Review, 33(5), 903-933.

Schaltegger, C. A., And L. P. Feld (2009): "Do large cabinets favor large governments? Evidence on the fiscal commons problem for Swiss Cantons," Journal of Public Economics, 93(12), 35 - 47.

Thistlethwaite, D., And D. Campell (1960): "Regression-Discontinuity analysis: an alternative to the ex post facto experiment," Journal of Educational Psychology, 51 (6), 309-317.

Tsebelis, G. (1995): "Decision Making in Political Systems: Veto Players in Presidentialism, Parliamentarism, Multicameralism and Multipartyism," British Journal of Political Science, 25(3), pp. 289-325.

VAN DER KLAAUw, W. (2002): "Estimating the Effect of Financial Aid Offers on College Enrollment: A Regression-Discontinuity Approach," International Economic Review, 43(4), 1249-1287.

VogL, T. S. (2011): "Race and the Politics of Close Elections," Discussion paper. 
Weingast, B. R., K. A. Shepsle, and C. Johnsen (1981): "The Political Economy of Benefits and Costs: A Neoclassical Approach to Distributive Politics," Journal of Political Economy, 89(4), 642-64. 


\section{A Appendix}

Table 5: Descriptive statistics for the outcome variables

\begin{tabular}{|c|c|c|c|c|c|}
\hline & (1) & (2) & (3) & (4) & (5) \\
\hline & Mean & Std. dev & Median & $25 \%$ ile & $75 \%$ ile \\
\hline & \multicolumn{5}{|c|}{ Panel 1: Spending } \\
\hline Total spending & 1570.8 & 598.5 & 1460.4 & 1276.3 & 1710.6 \\
\hline Investment spending & 374.0 & 227.0 & 329.8 & 224.1 & 465.6 \\
\hline \multirow[t]{2}{*}{ Spending on personnel } & 248.4 & 96.1 & 231.5 & 187.3 & 287.5 \\
\hline & \multicolumn{5}{|c|}{ Panel 2: Debt } \\
\hline \multirow[t]{2}{*}{ Debt total } & 710.1 & 588.4 & 602.8 & 328.0 & 941.4 \\
\hline & \multicolumn{5}{|c|}{ Panel 3: Tax rate multipliers } \\
\hline Trade tax multiplier & 320.9 & 23.5 & 300 & 320 & 330 \\
\hline Prop. tax A multiplier & 321.9 & 56.3 & 295 & 310 & 350 \\
\hline Prop. tax B multiplier & 317.0 & 48.4 & 390 & 300 & 340 \\
\hline
\end{tabular}


Table 6: Further fiscal variables

\begin{tabular}{|c|c|c|c|c|}
\hline & (1) & $(2)$ & (3) & (4) \\
\hline & \multicolumn{4}{|c|}{ RDD } \\
\hline & $2 \%$ & $2 \% \mathrm{wVS}$ & $1 \%$ & $1 \% \mathrm{w}$ VS \\
\hline & \multicolumn{4}{|c|}{ Panel 1: Debt } \\
\hline \multirow[t]{4}{*}{ Debt total } & 75.299 & 69.505 & $119.077^{* *}$ & 82.243 \\
\hline & $(47.342)$ & $(45.985)$ & $(51.902)$ & $(83.453)$ \\
\hline & {$[146]$} & {$[2732]$} & {$[67]$} & {$[2732]$} \\
\hline & & Panel 2 & Tax rates & \\
\hline \multirow[t]{3}{*}{ Trade tax rate multiplier } & -0.176 & -0.370 & 0.838 & -0.731 \\
\hline & (1.669) & $(1.293)$ & $(2.423)$ & $(2.365)$ \\
\hline & {$[147]$} & {$[2813]$} & {$[67]$} & {$[2813]$} \\
\hline \multirow[t]{3}{*}{ Prop tax A rate multiplier } & 3.064 & 2.022 & 4.117 & 3.765 \\
\hline & $(2.217)$ & $(2.090)$ & $(3.096)$ & $(3.860)$ \\
\hline & {$[144]$} & {$[2812]$} & {$[65]$} & {$[2812]$} \\
\hline \multirow[t]{4}{*}{ Prop tax B rate multiplier } & $8.293^{* *}$ & 4.174 & $17.349^{* * *}$ & $17.393^{* * *}$ \\
\hline & $(4.114)$ & $(3.539)$ & $(5.993)$ & $(6.572)$ \\
\hline & {$[146]$} & {$[2822]$} & {$[65]$} & {$[2822]$} \\
\hline & \multicolumn{4}{|c|}{ Panel 3: Areas of spending } \\
\hline \multirow[t]{3}{*}{ Spending on Personnel } & $9.474^{* *}$ & -0.659 & 12.176 & 11.829 \\
\hline & $(4.577)$ & (4.098) & $(8.472)$ & $(7.461)$ \\
\hline & {$[148]$} & {$[2804]$} & {$[68]$} & {$[2804]$} \\
\hline \multirow[t]{3}{*}{ Investment spending } & 32.178 & 14.054 & 64.648 & 35.305 \\
\hline & $(27.393)$ & $(24.685)$ & $(46.566)$ & $(45.229)$ \\
\hline & {$[147]$} & [2804] & {$[67]$} & {$[2804]$} \\
\hline
\end{tabular}

Notes: Significance levels: ${ }^{*} p<0.10,{ }^{* *} p<0.05,{ }^{* * *} p<0.01$. Standard errors in parentheses, number of observations in squared parentheses. Here, we present the results of further fiscal variables in our estimation design. Each coefficient represents a separate regression using a dummy for whether there was an absolute majority $(D=1)$, the dependent variable is shown in the left column. Outliers were eliminated for all specifications by restricting the sample to the 1-99 percentiles of the outcome variable. All columns use RDD specifications as described above and include the respective lagged dependent variable in the estimation. Column 1 and 3 use a limited sample specifications in which we use only observations for which the margin of closeness was less then 2 percent and 1 percent respectively. Columns 2 and 4 add a quadratic vote share control function to that approach which is then estimated out of the entire sample. Each specification includes population controls, year dummies and council size if appropriate. Source: Own calculations. 
Table 7: Robustness: Alternative specification

\begin{tabular}{lcccccc}
\hline \hline & $(1)$ & $(2)$ & $(3)$ & $(4)$ & $(5)$ & $(6)$ \\
\cline { 2 - 7 } & \multicolumn{5}{c}{ RDD (1\% closeness with control function) } \\
\cline { 2 - 7 } & linear & cubic & 2nd strongest & interacted & non flex & no mayor restr. \\
\hline \multirow{5}{*}{ Total spending } & 117.507 & 97.257 & 86.050 & 73.279 & 137.505 & 104.543 \\
& $(94.163)$ & $(95.538)$ & $(95.253)$ & $(96.416)$ & $(91.582)$ & $(87.922)$ \\
\hline \multirow{5}{*}{ Total spending } & $367.461^{* *}$ & $352.747^{*}$ & $309.850^{*}$ & $301.398^{*}$ & $375.467^{* *}$ & $321.858^{* *}$ \\
& $(175.708)$ & $(180.735)$ & $(176.368)$ & $(181.419)$ & $(172.067)$ & $(160.067)$ \\
\hline
\end{tabular}

Notes: Significance levels: ${ }^{*} p<0.10,{ }^{* *} p<0.05,{ }^{* * *} p<0.01$. Standard errors in parentheses. Each coefficient represents a separate regression using a dummy for whether there was an absolute majority $(D=1)$, the dependent variable is shown in the left column. Outliers were eliminated for all specifications by restricting the sample to the 1-99 percentiles of the outcome variable. Each column represents another specification test. All columns use the 1\% closeness definition and estimate the effect from the entire sample including a vote share control function. Column 1 uses a linear control function in the vote share of the strongest party, while column 2 uses a cubic specification. Columns 3 and 4, then, also inculde the vote share of the second strongest party as a control function. in column 3 this additional control function is quadratic and in column 4 we use a quadratic specification in both variables and additional quadratic interactions. In column 5, we use a quadratic control function that is not flexible for the two sets of observations (absolute majority yes/no). Finally, column 6 tests a specification in which we drop the limitation that the mayor has to be of the strongest party for estimating the vote share control function (for the close elections that identify the effect, the restriction is maintained). Here, we use the full set of observation and the baseline specification with quadratic control function in the vote share of the strongest party. Each specification includes population controls, year dummies, council size and the lagged dependent variable from the previous election period. All control functions are flexible for the two sets of observations (except in column 5).

Source: Own calculations. 
Table 8: Validity: Predetermined variables

\begin{tabular}{|c|c|c|c|c|}
\hline & $(1)$ & $(2)$ & $(3)$ & $(4)$ \\
\hline & \multicolumn{4}{|c|}{ RDD } \\
\hline & $2 \%$ & $2 \% \mathrm{wVS}$ & $1 \%$ & $1 \% \mathrm{w} \mathrm{VS}$ \\
\hline & \multicolumn{4}{|c|}{ Panel 1: Political variables } \\
\hline Absolute majority in t-1 & $\begin{array}{l}-0.057 \\
(0.080)\end{array}$ & \multicolumn{3}{|c|}{$\begin{array}{c}0.029 \\
(0.125)\end{array}$} \\
\hline Number of parties & $\begin{array}{c}0.120 \\
(0.124)\end{array}$ & $\begin{array}{l}-0.053 \\
(0.106)\end{array}$ & $\begin{array}{c}-0.031 \\
(0.198)\end{array}$ & $\begin{array}{c}-0.349^{*} \\
(0.191)\end{array}$ \\
\hline Council size & $\begin{array}{c}0.076 \\
(0.241)\end{array}$ & $\begin{array}{l}-0.050 \\
(0.101)\end{array}$ & $\begin{array}{c}-0.462^{*} \\
(0.274)\end{array}$ & $\begin{array}{c}0.060 \\
(0.182)\end{array}$ \\
\hline \multirow[t]{2}{*}{ Population number } & $\begin{array}{c}41.430 \\
(387.977)\end{array}$ & $\begin{array}{c}220.106 \\
(246.300)\end{array}$ & $\begin{array}{c}59.546 \\
(454.161)\end{array}$ & $\begin{array}{c}122.060 \\
(443.329)\end{array}$ \\
\hline & \multicolumn{4}{|c|}{ Panel 2: Fiscal variables } \\
\hline Total spending in t-1 & $\begin{array}{l}-75.562 \\
(61.189)\end{array}$ & $\begin{array}{c}-87.816 \\
(76.966)\end{array}$ & $\begin{array}{l}-65.049 \\
(95.690)\end{array}$ & $\begin{array}{c}-79.342 \\
(140.596)\end{array}$ \\
\hline Investment spending in t-1 & $\begin{array}{c}-8.904 \\
(28.878)\end{array}$ & $\begin{array}{l}-20.372 \\
(34.706)\end{array}$ & $\begin{array}{c}29.032 \\
(39.504)\end{array}$ & $\begin{array}{c}8.066 \\
(63.385)\end{array}$ \\
\hline Spending on Personnel in t- 1 & $\begin{array}{c}-5.480 \\
(10.180)\end{array}$ & $\begin{array}{c}0.219 \\
(9.661)\end{array}$ & $\begin{array}{c}-2.178 \\
(16.506)\end{array}$ & $\begin{array}{c}-9.138 \\
(17.643)\end{array}$ \\
\hline Debt total in $\mathrm{t}-1$ & $\begin{array}{l}-41.360 \\
(65.138)\end{array}$ & $\begin{array}{c}27.856 \\
(69.558)\end{array}$ & $\begin{array}{l}-20.539 \\
(93.062)\end{array}$ & $\begin{array}{c}25.848 \\
(125.794)\end{array}$ \\
\hline Trade Tax rate in $t-1$ & $\begin{array}{c}-7.292^{* *} \\
(3.400)\end{array}$ & $\begin{array}{l}-4.299 \\
(2.796)\end{array}$ & $\begin{array}{c}-0.554 \\
(5.383)\end{array}$ & $\begin{array}{c}0.595 \\
(5.132)\end{array}$ \\
\hline Property Tax A rate in $\mathrm{t}-1$ & $\begin{array}{c}-14.265 \\
(9.417)\end{array}$ & $\begin{array}{c}-13.170^{*} \\
(7.611)\end{array}$ & $\begin{array}{c}1.685 \\
(13.652)\end{array}$ & $\begin{array}{c}-5.062 \\
(13.907)\end{array}$ \\
\hline Property Tax B rate in t- 1 & $\begin{array}{l}-4.426 \\
(8.140)\end{array}$ & $\begin{array}{l}-7.450 \\
(6.416)\end{array}$ & $\begin{array}{c}15.612 \\
(12.145)\end{array}$ & $\begin{array}{c}8.787 \\
(11.720)\end{array}$ \\
\hline $\mathrm{N}$ & {$[149]$} & {$[2860]$} & [68] & {$[2860]$} \\
\hline
\end{tabular}

Notes: Significance levels: ${ }^{*} p<0.10,{ }^{* *} p<0.05,{ }^{* * *} p<0.01$. Standard errors in parentheses. We present the results of running predetermined variables on our estimation design. Each coefficient represents a separate regression using a dummy for whether there was an absolute majority $(D=1)$, the dependent variable is shown in the left column. All columns use RDD specifications as described above. Column 1 and 3 use a limited sample specifications with margins of closeness of 2 and 1 percent respectively. Columns 2 and 4 add a quadratic vote share control function to that approach and use the entire sample. Each specification includes population controls, year dummies and council size if appropriate. Source: Own calculations. 
Table 9: Validity: Tests at other thresholds

\begin{tabular}{|c|c|c|c|c|}
\hline & $(1)$ & $(2)$ & $(3)$ & $(4)$ \\
\hline & \multicolumn{4}{|c|}{ RDD } \\
\hline & $2 \%$ & $2 \% \mathrm{wVS}$ & $1 \%$ & $1 \% \mathrm{w} \mathrm{VS}$ \\
\hline \multirow[b]{2}{*}{ Total spending } & \multicolumn{4}{|c|}{ Panel 1: absolute "majority" } \\
\hline & $\begin{array}{c}-36.088 \\
(52.370) \\
{[142]}\end{array}$ & $\begin{array}{c}-24.541 \\
(53.226) \\
{[2808]}\end{array}$ & $\begin{array}{c}9.588 \\
(72.344) \\
{[77]}\end{array}$ & $\begin{array}{c}-3.142 \\
(73.239) \\
{[2812]}\end{array}$ \\
\hline \multirow[b]{2}{*}{ Total spending } & \multicolumn{4}{|c|}{ Panel 2: absolute super-majority } \\
\hline & $\begin{array}{c}-63.461 \\
(61.224) \\
{[101]}\end{array}$ & $\begin{array}{c}-64.231 \\
(63.981) \\
{[2808]}\end{array}$ & $\begin{array}{c}-87.122 \\
(109.382) \\
{[47]}\end{array}$ & $\begin{array}{c}-81.795 \\
(95.442) \\
{[2812]}\end{array}$ \\
\hline $\begin{array}{l}\text { Notes: Significa } \\
\text { errors in parentl } \\
\text { 1, we highlight } \\
\text { servations are tr } \\
\text { majority thresh } \\
\text { tions in which tl } \\
\text { to cases in whic } \\
\text { test. Here, we c } \\
\text { absolute majorit } \\
\text { using a dummy } \\
\text { variable is total } \\
\text { above. Column } \\
\text { closeness of } 2 \text { ar } \\
\text { vote share contr } \\
\text { specification inc }\end{array}$ & $\begin{array}{l}\text { ice levels: * } \\
\text { eses. We sh } \\
\text { he results of } \\
\text { eated when } \\
\text { ld. We effec } \\
\text { e largest pa } \\
\text { they were } \\
\text { ompare the } \\
\text { threshold. } \\
\text { for whether } \\
\text { spending. A } \\
1 \text { and } 3 \text { use } \\
\text { d } 1 \text { percent } \\
l \text { function tc } \\
\text { udes popula }\end{array}$ & $\begin{array}{l}p<0.10, * * \\
\text { w the estim } \\
\text { our estimati } \\
\text { hey just gai } \\
\text { ively compar } \\
\text { ty was two s } \\
\text { ne seat sho } \\
\text { ffect of one } \\
\text { Each coeffici } \\
\text { he placebo } \\
\text { l columns u } \\
\text { a limited sar } \\
\text { espectively. } \\
\text { that approa } \\
\text { ion controls }\end{array}$ & $\begin{array}{l}p<0.05, * * * \\
\text { tes of two pli } \\
\text { opproach i } \\
\text { an extra sea } \\
\text { spending ou } \\
\text { ats short of } t \\
\text {. In panel } 2 \\
\text { dditional sea } \\
\text { nt represents } \\
\text { as turn on (1 } \\
\text { e RDD specif } \\
\text { ple specificat } \\
\text { Columns } 2 \text { ar } \\
\text { h and use the } \\
\text { year dummie }\end{array}$ & $\begin{array}{l}p<0.01 \text {. Standard } \\
\text { cebo tests. In panel } \\
\text { we specify that ob- } \\
\text { below the absolute } \\
\text { comes from observa- } \\
\text { ne absolute majority } \\
\text { we do the opposite } \\
\text { that was above the } \\
\text { separate regression } \\
=1 \text { ), the dependent } \\
\text { cations as described } \\
\text { ons with margins of } \\
\text { d } 4 \text { add a quadratic } \\
\text { entire sample. Each } \\
\text { s and council size if }\end{array}$ \\
\hline
\end{tabular}


Figure 1: Histogram of frequencies in different bands of closeness

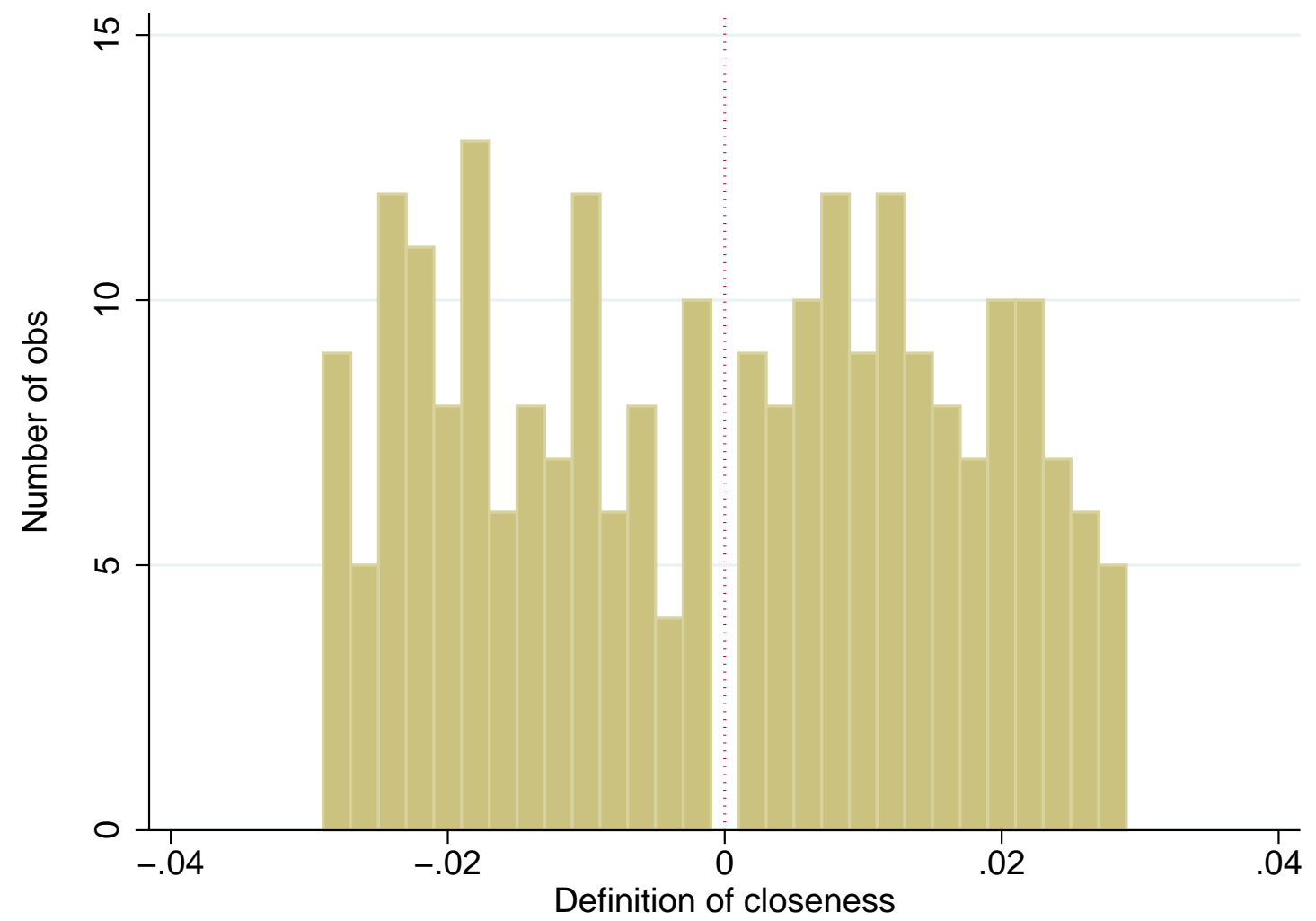

Notes: In this figure, we show the number of observations within different band of our closeness definition. We used our perturbation approach with varying definitions of closeness in steps of 0.002 (standard deviation from vote share) starting from 0.002 to 0.03 . For each definition of closeness, we perturbed the vote vector 200 times and determined which seat allocation was close (see description above). The graphs highlights the frequency of observations that where close to being an absolute majority (left to zero) or where close to losing the absolute majority status (right to zero). Source: Own calculations. 
Figure 2: Distribution of vote share of the largest party (by absolute majority)
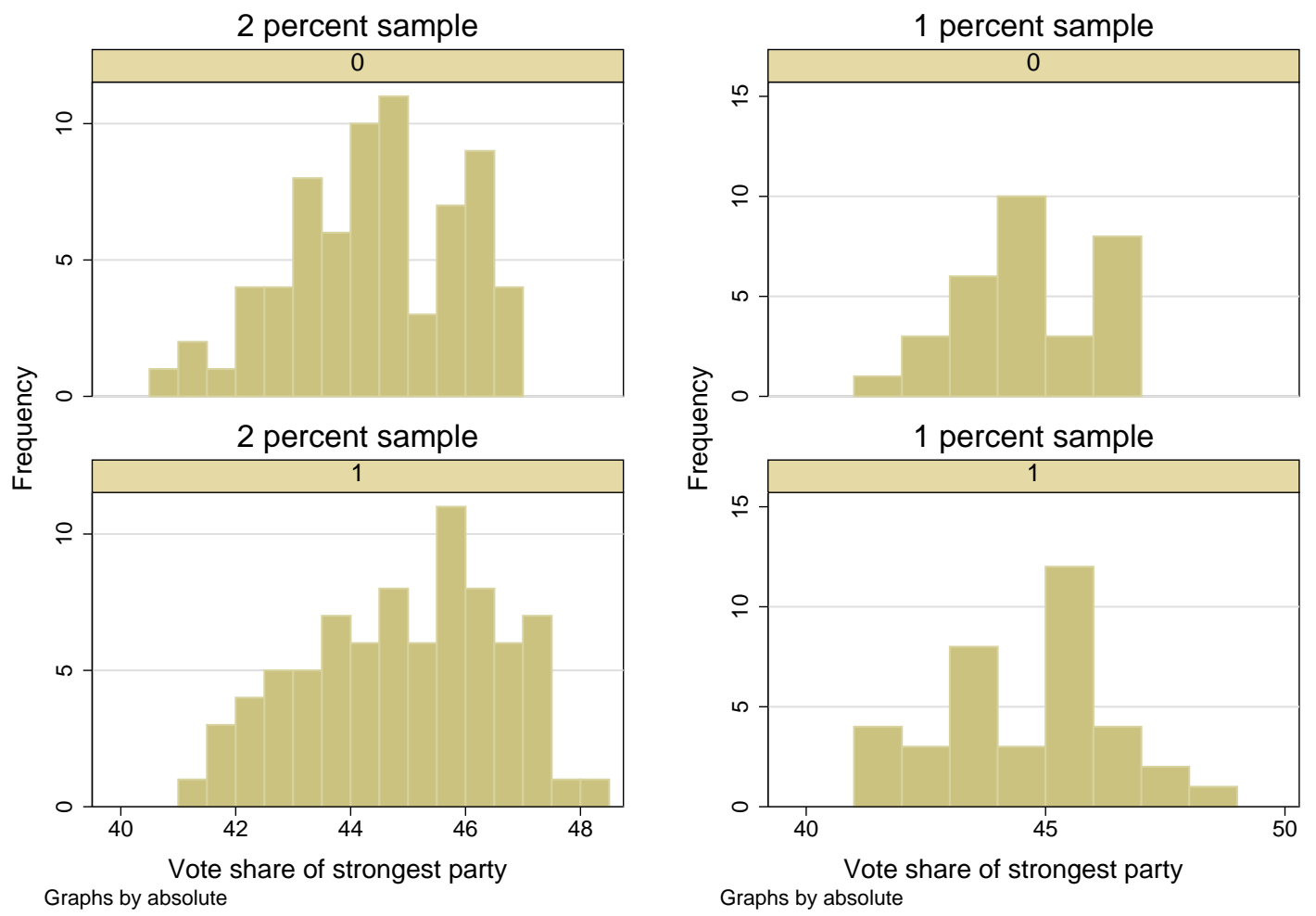

Notes: This figure graphically illustrates the distribution of the vote share of the largest party in the council by status in the absolute majority (yes or no). The two graphs on the left side show the respective distributions in the 2 percent closeness sample (no absolute majorities at the top and absolute majorities at the bottom). The two graphs on the right show the respective histograms within the 1 percent closeness sample. Source: Own calculations. 
Figure 3: Distribution of the CSU vote share (by absolute majority)

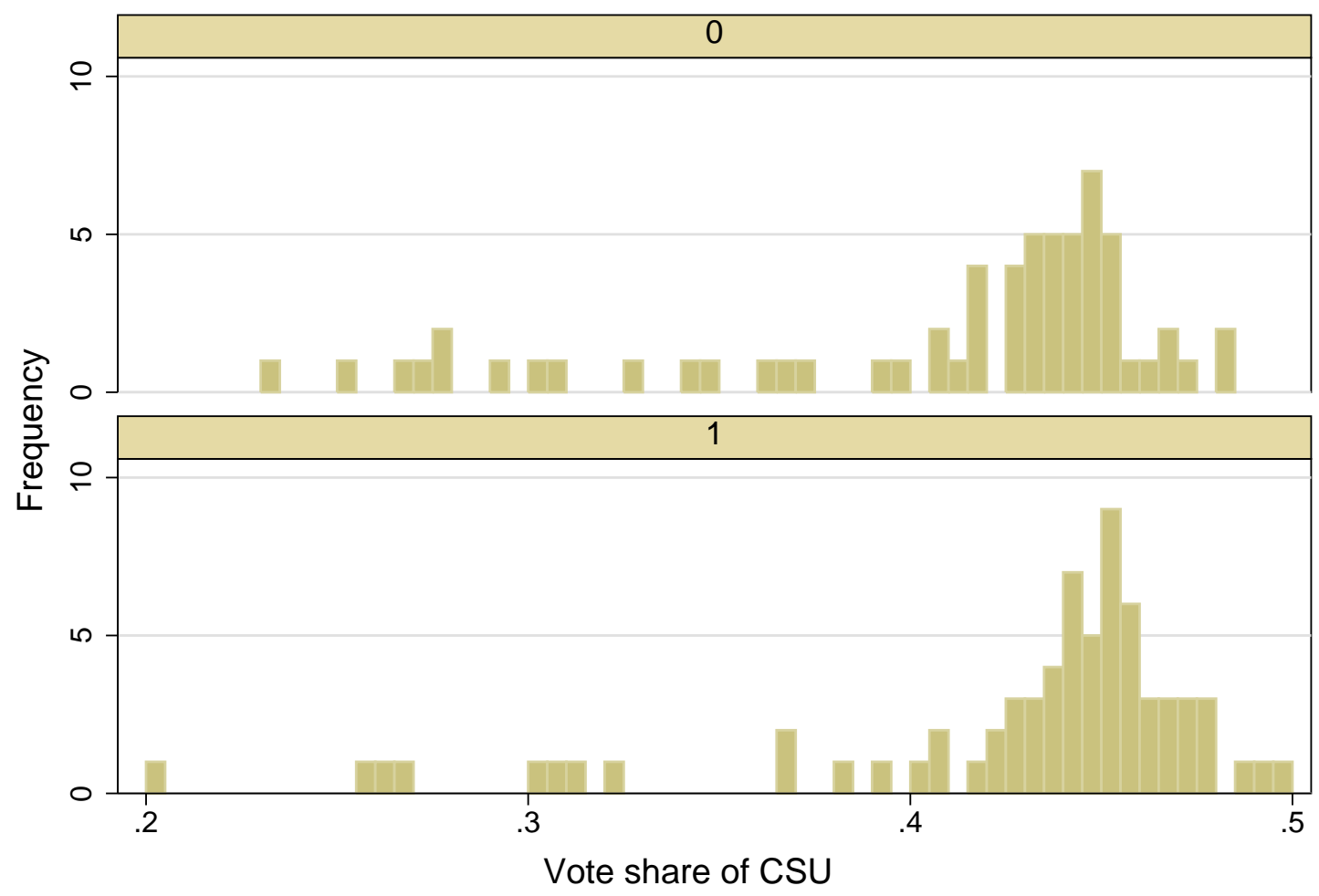

Graphs by absolute

Notes: This figure shows the distribution of the vote share of the CSU party which is the dominating party in Bavaria by status in the absolute majority (yes or no). The graph on the top shows the distribution of the vote share in observations that marginally did not receive the absolute majority treatment. In the bottom, we highlight the similar distribution within the sample of observations that just received enough votes to obtain the absolute majority. The two graphs show the respective histograms within the 2 percent closeness sample. The histograms use a bandwidth of $0.5 \%$ in the vote share. Source: Own calculations. 
Figure 4: Distribution of the municipal population size (by absolute majority)

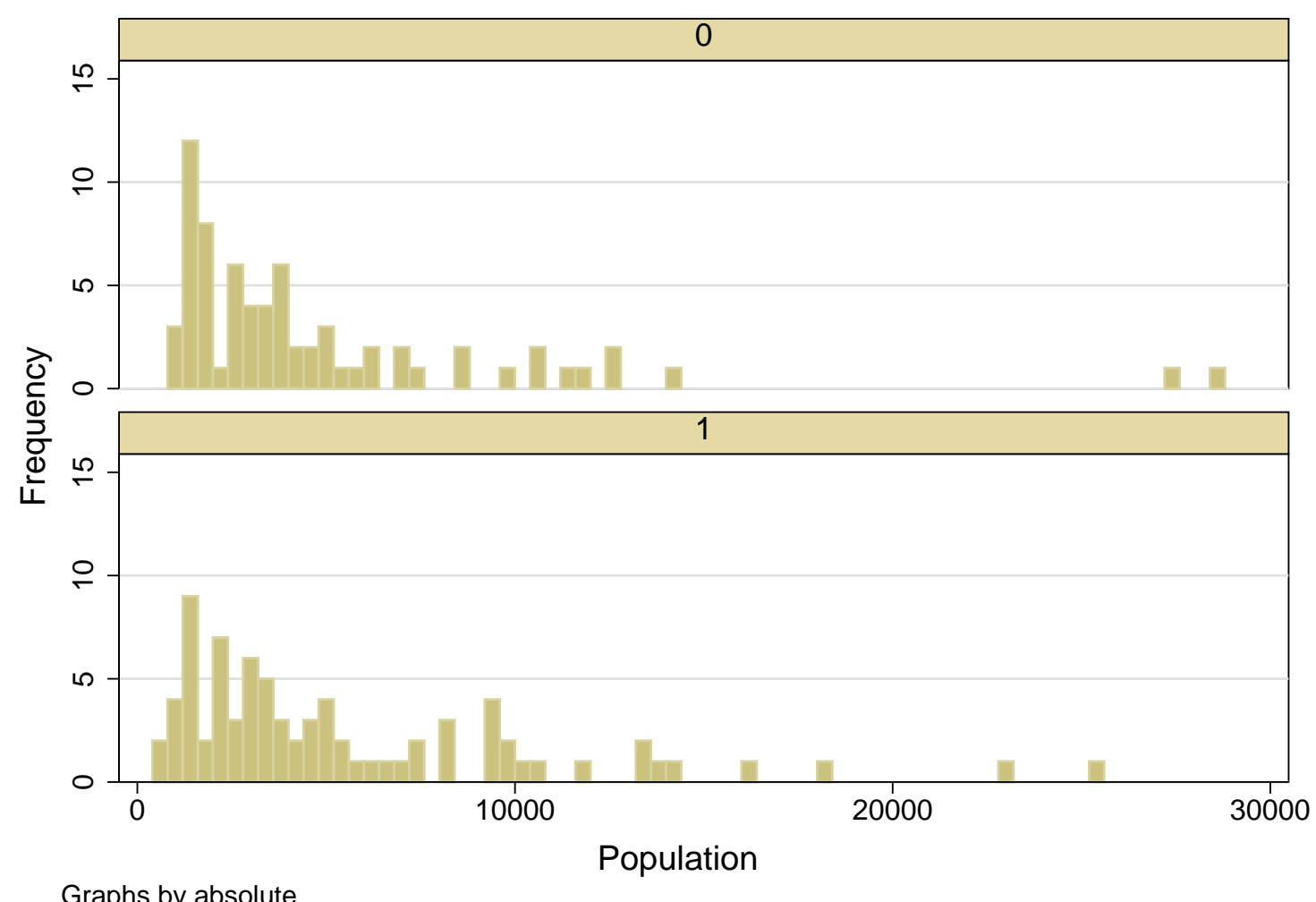

Notes: This figure highlights the distribution of the population size in the municipalities by status in the absolute majority (yes or no). The upper panel shows the distribution of population within observations that marginally did not receive the absolute majority treatment. In the lower panel, we present the similar distribution within the sample of observations that just received enough votes to obtain the absolute majority. The two graphs show the respective histograms within the 2 percent closeness sample. The histograms use a bandwidth of 400 inhabitants. Source: Own calculations. 